A Companion to the Abbey of Cluny in the Middle Ages

For use by the Author only | (C) 2022 Koninklijke Brill NV 


\section{Brill's Companions to European History}

VOLUME 27

The titles published in this series are listed at brill.com/bceh

For use by the Author only | (C) 2022 Koninklijke Brill NV 


\title{
A Companion to the Abbey of Cluny in the Middle Ages
}

\author{
Edited by
}

Scott G. Bruce and Steven Vanderputten

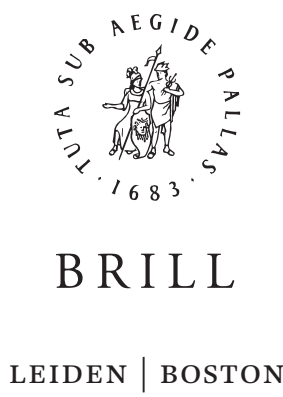

For use by the Author only | (C) 2022 Koninklijke Brill NV 
Steven Vanderputten wishes to acknowledge the Research Foundation-Flanders (FWO) for financially supporting his work on this volume in the context of the project "The Quest for Otherness. Uncovering Narratives of Religious Distinction in the Long Tenth Century' (2020-24).

Cover illustration: Duke William Founds the Abbey of Cluny, from Paris, BNF Latin 17716, fol. 85. Copyright Bibliothèque Nationale de France.

\section{Library of Congress Cataloging-in-Publication Data}

Names: Bruce, Scott G. (Scott Gordon), 1967- editor. | Vanderputten, Steven, editor.

Title: A companion to the Abbey of Cluny in the Middle Ages / edited by Scott G. Bruce, and Steven Vanderputten.

Description: Boston, Massachusetts : Brill, [2022] | Series: Brill's companions to European history, 2212-7410 ; vol 27 | Includes bibliographical references and index.

Identifiers: LCCN 2021042741 (print) | LCCN 2021042742 (ebook) | ISBN 9789004470132 (hardback) | ISBN 9789004499232 (ebook)

Subjects: LCSH: Cluny (Benedictine abbey)-History-To 1500.

Classification: LCC BX2615.C63 C66 2022 (print) | LCC BX2615.C63 (ebook) | DDC 271/.14-dc23

LC record available at https://lccn.loc.gov/2021042741

LC ebook record available at https://lccn.loc.gov/2021042742

Typeface for the Latin, Greek, and Cyrillic scripts: "Brill". See and download: brill.com/brill-typeface.

\section{ISSN 2212-7410}

ISBN 978-90-04-47013-2 (hardback)

ISBN 978-90-04-49923-2 (e-book)

Copyright 2022 by Koninklijke Brill NV, Leiden, The Netherlands.

Koninklijke Brill NV incorporates the imprints Brill, Brill Nijhoff, Brill Hotei, Brill Schöningh, Brill Fink, Brill mentis, Vandenhoeck \& Ruprecht, Böhlau Verlag and V\&R Unipress.

All rights reserved. No part of this publication may be reproduced, translated, stored in a retrieval system, or transmitted in any form or by any means, electronic, mechanical, photocopying, recording or otherwise, without prior written permission from the publisher. Requests for re-use and/or translations must be addressed to Koninklijke Brill NV via brill.com or copyright.com.

This book is printed on acid-free paper and produced in a sustainable manner. 